\title{
Identifikasi Tahu Berformalin dengan Electronic Nose Menggunakan Jaringan Syaraf Tiruan Backpropagation
}

\author{
Wida Astuti* ${ }^{1}$, Danang Lelono ${ }^{2}$,Faizah $^{3}$ \\ ${ }^{1}$ Program Studi Elektronika dan Instrumentasi, JIKE, FMIPA, UGM, Yogyakarta \\ ${ }^{2,3}$ Jurusan Ilmu Komputer dan Elektronika, FMIPA UGM, Yogyakarta \\ e-mail: *11 widamuhtar@gmail.com, 러anang@ugm.ac.id, ${ }^{3}$ faizah@ugm.ac.id
}

\begin{abstract}
Abstrak
Selama ini untuk mengidentifikasi tahu murni dan berformalin berdasarkan warna dan aroma dengan melibatkan human tester. Namun tester tahu ini masih memiliki kelemahan seperti bersifat subyektif. Disamping itu metode analitik kimia standard membutuhkan biaya yang besar dan tenaga ahli dalam menganalisanya. Pada dasarnya aroma tahu sangat ditentukan senyawa volatile seperti heksanal, etanol dan 1-hexanol, sedangkan aroma formalin pada tahu ditentukan oleh senyawa volatile seperti $\mathrm{OH}$, $\mathrm{CO}$ dan gugus hidrokarbon. Electronic nose berbasis larik sensor gas tak terseleksi (unselected) memiliki kemampuan untuk menganalisa sampel dengan komposisi yang kompleks sehingga dapat diketahui karakteristik dan analisa kualitatif dari sampel tersebut. Stimulus aroma dirubah oleh electronic nose menjadi fingerprint data yang kemudian digunakan untuk proses ekstraksi ciri menggunakan metode differensial. Hasil dari ekstraksi ciri digunakan untuk proses pelatihan jaringan syaraf tiruan backpropagation untuk mendapatkan parameter optimal. Parameter yang telah dioptimasi ini kemudian diujikan pada sampel tahu acak. Berdasarkan hasil pengujian, JST-BP dapat mengidentifikasi sampel dengan tingkat akurasi 100\%. Sehingga identifikasi tahu murni dan tahu berformalin dengan electronic nose menggunakan analisa jaringan syaraf tiruan backpropagation telah berhasil dilakukan.
\end{abstract}

Kata kunci-Electronic nose, Jaringan Syaraf Tiruan (JST), backpropagation, tahu.

\begin{abstract}
During this time to identify pure and formalin tofu based on color and aroma involving human taster. But this tofu tester still has weaknesses such as subjective. Besides that, the standard chemical analytical methods requires a high cost and need expertise to analyzing it. Basically aroma of tofu is determined by volatile compounds such as heksanal, ethanol, and 1hexanol, while aroma of formalin tofu is determined by volatile compounds such as $\mathrm{OH}, \mathrm{CO}$, and hydrocarbon. Electronic nose based on unselected gas sensor array has the ability to analyze samples with complex compositions that can be known characteristics and qualitative analysis of the samples. Stimulus aroma is transformed by electronic nose into fingerprint data then it is used by feature extraction process using the differential method. The results of feature extraction is used to process the back propagation neural network training to obtain optimal parameters. The parameters have been optimized is then tested on a random tofus. Based on test results, ANN-BP can identify samples with $100 \%$ accuracy rate so that the identification of a pure tofu and tofu formalin with electronic nose using back propagation neural network analysis has been successfully carried out.
\end{abstract}

Keywords-Electronic nose, Artificial neural network, Backpropagation, tofu. 


\section{PENDAHULUAN}

A kibat maraknya kasus tahu berformalin ini baik pemerintah dan masyarakat telah banyak melakukan antisipasi diantaranya dengan mengidentifikasi tahu berformalin menggunakan metode yang sederhana sampai dengan yang canggih. Metode sederhana yang selama ini masih dilakukan adalah dengan menggunakan human tester. Namun hal yang demikian ini masih bersifat subyektif. Disamping itu metode analitik kimia standard membutuhkan biaya yang besar dan tenaga ahli dalam menganalisanya.

Hadirnya teknologi biomimetik telah memunculkan sensor aroma yang memungkinkan untuk mengekstrak informasi dari sebuah sampel yang diberikan. Kemampuan dari sistem tersebut dapat menganalisa sampel yang memiliki komposisi yang kompleks sehingga dapat diketahui karakteristiknya dan analisa kualitatifnya. Prinsip dasar dari sistem electronic nose mengkombinasikan sinyal dari sensor non-spesifik (non-specific) dan tumpang tindih (overlapping) dengan rutin-rutin pengenalan pola (pattern ricognition) [1]. Sensor aroma (electronic nose) adalah sebuah mesin yang dirancang untuk mendeteksi dan mendiskriminasi antara aroma yang kompleks menggunakan larik sensor. Larik sensor tersebut terdiri dari sensor-sensor aroma umum yang dapat digunakan untuk berbagai aroma sensitif dari bahan biologi atau kimia. Oleh sebab itu di dalam sensor aroma ini tidak menggunakan sensor yang sifatnya selektif hanya untuk sebuah unsur atau senyawa saja hal ini disebabkan karena aroma terdiri ratusan unsur dan senyawa sehingga pola sinyal yang ditangkap oleh sensor gas bersifat tumpang tindih (overlapping) [2]. Sedangkan pengenalan pola pada sistem ini untuk reduksi data dan analisa struktur data berupa pengenalan poala terawasi (supervised pattern recognition) [3]. Adapun penggunaan jaringan syaraf tiruan atau JST (artificial neural network) saat ini dianggap sebagai salah satu perangkat yang penting pada kemometrika [4]. Secara umum karena JST merupakan perangkat non parametrik dimana parameternya mempunyai kemampuan beradaptasi (seperti jumlah neuron, lapisan dan epoch), kebanyakan skema pembelajarannya membutuhkan pengujian untuk mengoptimalkan struktur modelnya [5]. Oleh karena itu maka pada penelitian ini difokuskan penelitian untuk mengidentifikasi tahu berformalin dengan menggunakan electronic nose. Untuk mengidentifikasinya diperlukan sebuah komputasi berupa pengenalan pola berbasis jaringan syaraf tiruan backpropagation.

\section{METODE PENELITIAN}

\subsection{Bahan}

Bahan yang digunakan sebagai sampel dalam penelitian ini adalah tahu murni yang didapatkan dari pabrik tahu Desa Wisata Tanjung, Sleman, tahu yang direndam dalam larutan formalin 2\% dan tahu yang didapat dari berbagai tempat di Yogyakarta ( Pasar Kranggan, Pasar Colombo dan Swalayan ).

\subsection{Peralatan}

Peralatan yang digunakan dalam penelitian ini adalah electronic nose sistem terbuka yang telah dibuat oleh Iswanto (2014) dengan menggunakan 5 sensor gas TGS (TGS 2610, TGS 2620, TGS 2611, TGS 2602 dan TGS 2600). Oleh karena formalin merupakan bahan kimia yang mudah teroksidasi dan termasuk dalam golongan senyawa volatile, maka untuk mendeteksi bau formalin pada tahu, digunakan deret sensor gas yang sensitif terhadap gugus $\mathrm{OH}, \mathrm{CO}$ dan gugus hidrokarbon [6]. Diagram blok dari sistem e-nose yang digunakan dalam penelitian ini ditunjukkan pada Gambar 1.

IJEIS Vol. 6, No. 2, October 2016 : $211-220$ 


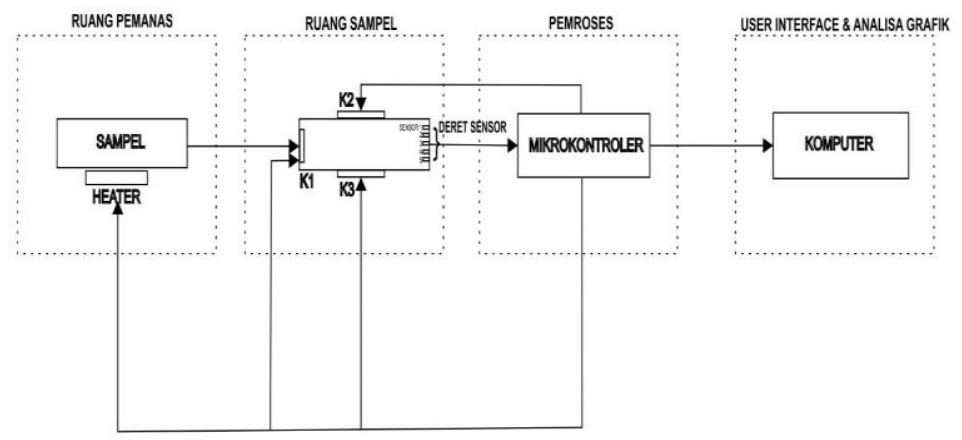

Gambar 1 Diagram blok sistem electronic nose

Pada Gambar 1 merupakan electronic nose yang digunakan terdiri atas larik sesnsor TGS, pemrosesan sinyal, user interface pada komputer yang menampilkan data secara online.

\subsection{Prosedur dan Pengumpulan Data}

2.3.1 Preparasi sampel

Penelitian ini menggunakan 3 sampel tahu (tahu murni, tahu formalin 2\% dan tahu dengan sampel acak). Setiap sampel tahu dibagi menjadi enam buah sampel dengan massa yang sama yaitu 20 gram. Jumlah keseluruhan sampel ada 18 buah. Sampel-sampel ditempatkan dalam wadah plastik untuk menyimpan sampel setelah di timbang. Semua sampel tahu yang total berjumlah 18 buah sampel kemudian diuji dengan electronic nose.

\subsubsection{Pengambilan dan pengolahan data}

Penelitian ini bertujuan untuk mengetahui apakah e-nose dapat mengklasifikasi sampel atau tidak. Pengujian dilakukan dengan menggunakan tahu murni, tahu formalin dan tahu yang dibeli dari berbagai tempat (Pasar Kranggan, Pasar Colombo, dan Swalayan). Tahapan-tahapan dalam pengambilan data selama 10 kali tiap sampel dengan variasi waktu odor off selama 3 menit dan odor on selama 2 menit. Untuk tahap pengambilan data sampel tahu murni dan tahu yang direndam pada formalin $2 \%$ dilakukan selama 6 hari per sampel dengan pengambilan selama 10 kali.

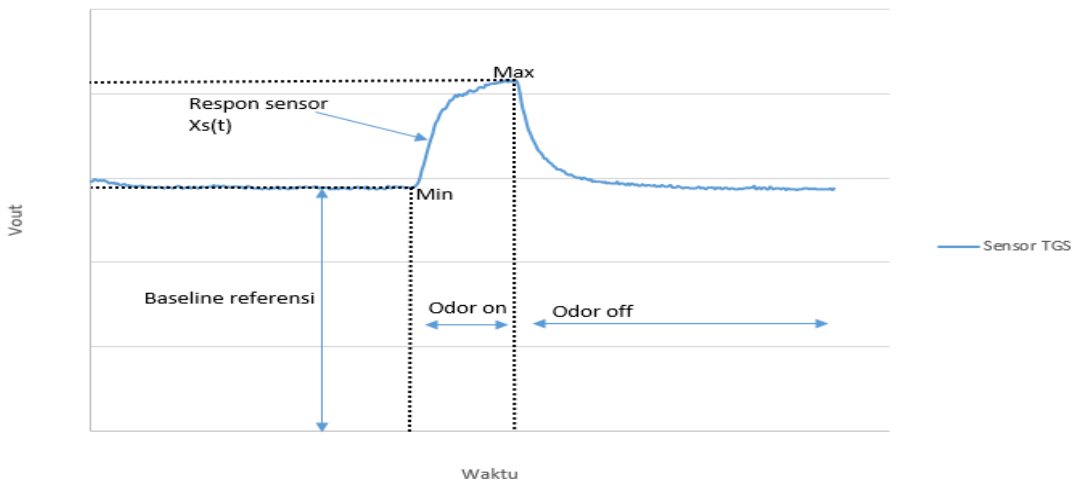

Gambar 2 Pengambilan data

Pada Gambar 2 menjelaskan dalam satu kali pengambilan data didapatkan nilai maksimum dan minimum pada setiap puncak dari hasil keluaran sensor, dari nilai tersebut akan digunakan untuk proses ekstraksi ciri dengan persamaan 1. Pada tahap ekstraksi ciri menggunakan metode differensial, penggunaan metode ini dengan menghitung nilai keluaran sensor (data) yang akan diekstrak untuk mendapatkan nilai-nilai yang mempresentasikan ciri spesifik dari data tersebut. Metode differensial disini bertujuan untuk mengurangi penyimpangan (drift) atau derau tambahan (additive noise) pada respon sensor dan mengatasi pergeseran nilai baseline dengan cara menyamakan nilai baseline. 
$\mathrm{i}=$ data ke $1,2,3, \ldots .10$

Xkis $=X \max -X \min , \mathrm{X}=$ respon sinyal sensor

$\mathrm{s}=$ sensor $1,2,3,4,5$

$\mathrm{k}=$ hari $1,2,3,4,5$

Karena setiap sampel dilakukan 10 kali percobaan maka akan didapatkan sebanyak sepuluh data. Lalu percobaan diulangi selama 6 hari. Data ini akan digunakan sebagai data untuk proses jaringan syaraf tiruan backpropagation (data pelatihan dan data uji). Jumlah data yang digunakan sebanyak 150 tahu murni dan 150 tahu berformalin, dengan 220 data sebagai pelatihan dan 80 data dipergunakan untuk menguji keakuratan sistem yang digunakan untuk mengenali pola masukan. Data latih yang dilatihkan pada JST-BP akan menghasilkan bobot. Selanjutnya diuji dengan data uji. Penentuan prosentase keberhasilan pengenalan dilakukan dengan cara membagi jumlah data uji yang dapat dikenali dengan benar dengan jumlah data uji keseluruhan.

\subsection{Rancangan Topologi Identifikasi Tahu Murni dan Tahu Berformalin}

Pada bagian ini akan dijelaskan mengenai rancangan topologi proses identifikasi tahu murni dan tahu berformalin. Jaringan syaraf tiruan digunakan sebagai sistem yang diharapkan dapat mengidentifikasi tahu murni dan tahu formalin berdasarkan informasi yang ada. Jaringan ini akan menerima masukan (input) berupa informasi-informasi yang berasal dari electronic nose. Electronic nose ini menggunakan 5 sensor TGS (Toguchi Gas Sensor).

Rancangan topologi jaringan syaraf tiruan ini berupa jaringan backpropagation atau jaringan propagasi balik. Jaringan backpropagation merupakan arsitektur jaringan syaraf tiruan yang mampu menyelesaikan permasalahan yang bersifat non linear. Berdasarkan hal tersebut maka rancangan topologi jaringan ini diharapkan mampu untuk mengidentifikasi tahu murni dan tahu formalin. Rancangan topologi jaringan syaraf tiruan pada sistem ini ditunjukkan pada Gambar 3

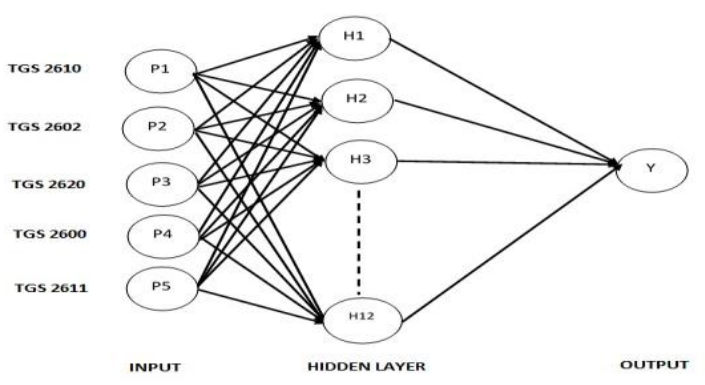

Gambar 3 Rancangan topologi JST untuk sistem tahu murni dan tahu berformalin

Rancangan topologi jaringan dipilih dengan pendekatan konstruktif, yaitu dengan suatu jaringan yang kecil dengan satu hidden layer kemudian mengembangkan jumlah unit tersembunyi serta bobot tambahan sampai didapatkan penyelesaian yang dikehendaki. Pada Gambar 4.11 terlihat bahwa jaringan syaraf tiruan yang digunakan memiliki 5 input layer, 12 lapisan tersembunyi, dan 1 output. Lapisan masukan (input layer) jaringan ini menerima 5 buah masukan (P1, P2, P3, P4, dan P5) berupa tegangan yang berasal dari 5 buah sensor aroma yaitu TGS2610 (P1), TGS2602 (P2), TGS2620 (P3), TGS2600 (P4), dan TGS2611 (P5). Satu lapisan tersembunyi atau hidden layer berjumlah 12 neuron. Terdapat 1 output $(\mathrm{Y})$ berupa identifikasi tahu murni dan tahu berformalin. 


\subsection{Rancangan GUI (Graphical User Interface)}

GUI merupakan tampilan program yang dirancang sedemikian rupa sehingga dapat digunakan oleh user dengan mudah. Fungsi dari aplikasi berbasis GUI yang dibuat dengan menggunakan Matlab digunakan untuk mengidentifikasi tahu murni dan tahu berformalin yang diujikan. Pada aplikasi berbasis GUI ini baik proses training dan proses uji dibuat dalam satu lingkungan (environment). Program GUI ini dibuat dengan software Matlab. Rancangan GUI ditunjukkan pada Gambar 4.

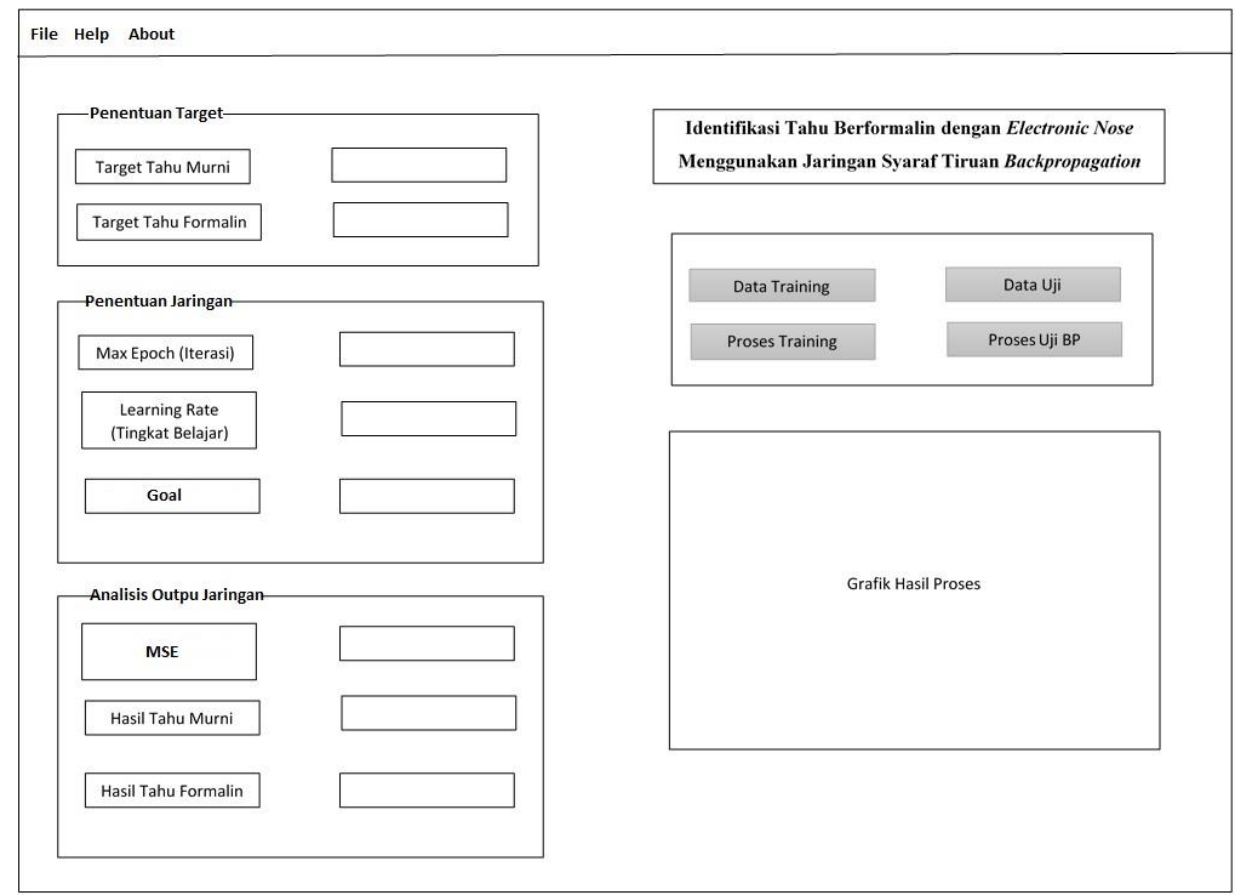

\section{HASIL DAN PEMBAHASAN}

\subsection{Analisa Hasil Pengambilan Data pada Tahu Murni dan Tahu Berformalin}

Pada penelitian ini, dirancang dan diimplementasikan sistem untuk mengidentifikasi tahu murni dan tahu berformalin. Untuk membuatnya diperlukan data yang diperoleh dari sinyal yang dihasilkan dari e-nose. Dari sinyal ini didapatkan informasi aspek yang berbeda pada setiap keluaran sensornya. Sinyal yang dihasilkan dari e-nose diperlihatkan pada Gambar 5.

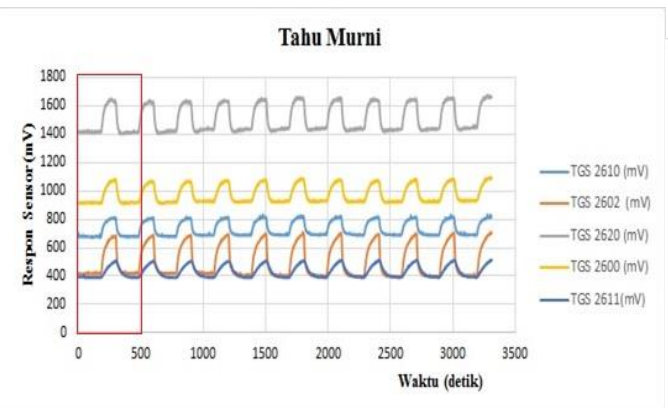

a

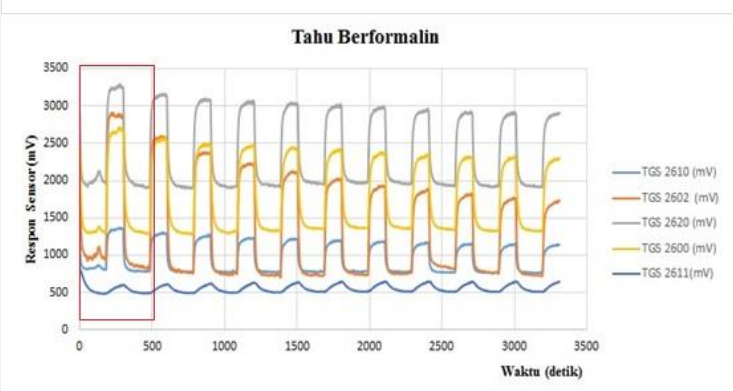

$\mathrm{b}$

Gambar 5 Grafik respons e-nose terhadap sampel (a) tahu murni dan (b) tahu berformalin

Respon pada masing-masing sensor terhadap sampel yang diberikan menghasilkan 10 puncak (peak) yang digrafikan dalam bentuk satuan tegangan $(\mathrm{mV})$ terhadap waktu (detik). 
Selanjutnya data tersebut melalui tahap ekstraksi ciri dengan menggunakan metode differensial, sesuai dengan persamaan 1. Pada tahap ekstraksi ciri dihitung setiap puncak yang telah dihasilkan. Data hasil ekstraksi ciri digunakan untuk melakukan pelatihan program jaringan dan sebagai data latih dan data uji untuk sistem. Sebagai output-nya merupakan identifikasi tahu murni atau tahu berformalin.

\subsection{Analisa Hasil Ekstraksi Ciri}

Ekstraksi ciri yang digunakan dalam analisis penelitian ini adalah metode differensial. Metode ini mencari nilai selisih antara nilai maksimum dan nilai baseline yaitu nilai minimum dari masing-masing puncak. Nilai baseline didapat pada saat proses flushing, sedangkan nilai maksimum dilakukan saat proses collecting. Nilai inilah yang akan digunakan sebagai data masukan pada proses identifikasi menggunakan jaringan syaraf tiruan backpropagation. Data tersebut digunakan untuk melakukan pelatihan program jaringan dan sebagai data latih dan data uji untuk sistem. Jumlah data yang digunakan sebanyak 150 data untuk tahu murni dan 150 data untuk tahu berformalin. Data tersebut dibagi menjadi 220 data sebagai data pelatihan dan 80 data dipergunakan untuk menguji keakuratan system yang digunakan untuk mengenali pola masukan. Nilai baseline dan nilai maksimum dapat ditunjukkan pada Gambar 6.

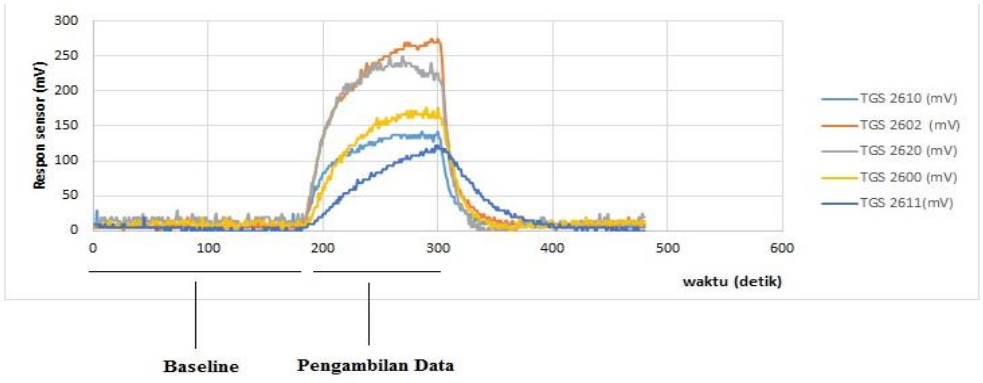

Gambar 6 Hasil dari proses ekstraksi ciri menggunakan metode differensial

\subsection{Pengujian Parameter Pelatihan Backpropagation}

Pengujian parameter pelatihan backpropagation bertujuan untuk mengetahui parameter terbaik dalam jaringan backpropagation pada identifikasi tahu murni dan tahu berformalin. Berbagai pengujian parameter dilakukan dengan cara memvariasi parameter-parameter pelatihan. Pengujian ini dilakukan dengan melihat pengaruh hasil dari variasi parameter pelatihan terhadap kecepatan pelatihan.

\subsubsection{Pelatihan jaringan dengan variasi epoch}

Variasi epoch yang dilakukan pada penelitian ini dengan cara memvariasi nilai epoch dari 1000 epoch sampai dengan 3000 epoch dengan kenaikan 500 epoch. Variasi yang digunakan ini bertujuan untuk melihat kinerja dari masing-masing epoch. Hasil pelatihan dapat dilihat pada Tabel 1.

Tabel 1 Hasil pelatihan jaringan dengan variasi epoch

\begin{tabular}{|c|c|c|c|}
\hline No & Variasi Jumlah Epoch & Error Pelatihan & Akurasi (\%) \\
\hline 1 & 1.000 & 0,0098024 & 99,02 \\
\hline $\mathbf{2}$ & $\mathbf{1 . 5 0 0}$ & $\mathbf{0 , 0 0 9 7 1 1 7}$ & $\mathbf{9 9 , 0 3}$ \\
\hline 3 & 2.000 & 0,0099645 & 99 \\
\hline 4 & 2.500 & 0,0097826 & 99,02 \\
\hline 5 & 3.000 & 0,0098545 & 99,01 \\
\hline
\end{tabular}

Variasi epoch yang dilakukan pada penelitian ini bertujuan untuk melihat tingkat kekonvergenan setelah melakukan proses iterasi. Konvergen yang dimaksud yaitu dimana 
semua persamaan akan terseleksikan dan menuju kesuatu nilai yang mendekati dari nilai yang diberikan sehingga jaringan sudah dapat mengenali pola yang diberikan, sehingga dapat dikatakan bahwa jaringan telah siap untuk melakukan tahap pengujian.

\subsubsection{Pelatihan untuk mencari jumlah neuron pada hidden layer}

Pada bagian ini akan dilakukan pelatihan jaringan dengan memvariasi jumlah neuron pada layer tersembunyi (hidden layer). Tujuan dari langkah ini adalah untuk menentukan jumlah neuron pada hidden layer yang menghasilkan kinerja terbaik selama proses pelatihan. Kinerja terbaik ditunjukkan pada Tabel 2 dengan MSE terkecil dan nilai epoch terkecil.

Tabel 2 Hasil training jaringan dengan variasi neuron pada hidden layer

\begin{tabular}{|c|c|c|}
\hline Neuron & Epoch & MSE \\
\hline 2 & 123 & 0,0097297 \\
\hline 3 & 97 & 0,0097384 \\
\hline 4 & 174 & 0,0097562 \\
\hline 6 & 135 & 0,0092833 \\
\hline 8 & 218 & 0,0097980 \\
\hline 10 & 113 & 0,0088268 \\
\hline $\mathbf{1 2}$ & $\mathbf{9 4}$ & $\mathbf{0 , 0 0 8 7 5}$ \\
\hline 16 & 264 & 0,00999 \\
\hline 20 & 199 & 0,00993 \\
\hline 25 & 333 & 0,00998 \\
\hline 30 & 333 & 0,00986 \\
\hline
\end{tabular}

Dari hasil pelatihan dengan cara memvariasi jumlah neuron pada satu lapisan tersembunyi didapatkan jaringan optimal sesuai hasil percobaan dibangun dengan jumlah neuron pada lapisan tersembunyi sebanyak 12 . Sehingga topologi atau arsitektur JST-BP yang digunakan yaitu 5-12-1.

\subsubsection{Pelatihan untuk Mencari Laju Pembelajaran Terbaik}

Pada langkah ini akan dilakukan variasi laju pembelajarn (learning rate) terhadap unjuk kerja jaringan yang dinyatakan dengan besar kecilnya MSE selama proses pelatihan dan waktu iterasi (epoch). Tujuan dari langkah ini untuk memperoleh nilai laju pembelajaran (learning rate) yang optimal ditunjukkan pada Tabel 3.

Tabel 3 Hasil training jaringan dengan variasi laju pembelajaran

\begin{tabular}{|c|c|c|}
\hline Learning Rate & Training Cycle (epoch) & MSE \\
\hline 0,001 & 277 & 0,0099492 \\
\hline 0,01 & 266 & 0,0097950 \\
\hline $\mathbf{0 , 1}$ & $\mathbf{2 4 8}$ & $\mathbf{0 , 0 0 9 6 3 7 4}$ \\
\hline 1 & 282 & 0,0099885 \\
\hline
\end{tabular}

Parameter laju pembelajaran (learning rate) juga sangat berpengaruh pada proses pelatihan. Begitu pula terhadap efektivitas dan kecepatan mencapai konvergensi dari pelatihan. Nilai optimum dan laju pembelajaran tergantung permasalahan yang diselesaikan, prinsipnya dipilih sedemikian rupa sehingga tercapai konvergensi yang optimal dalam proses pelatihan. Pada hasil penelitian yang didapat semakin besar nilai laju pembelajaran akan berimplikasi pada semakin besarnya iterasi.

\subsection{Hasil Proses Pelatihan (Training)}

Pada proses pelatihan jaringan digunakan arsitektur jaringan yang telah dibentuk dengan memperhatikan parameter pembelajaran yang digunakan, seperti parameter laju pembelajaran (learning rate), maksimum iterasi (epoch), jumlah neuron pada hidden layer, dan target error (goal). Hal lain yang perlu diperhatikan adalah banyaknya neuron pada lapisan 
input akan berpengaruh bagi keakuratan prediksi pada JST. Disamping itu data masukan juga digunakan sebagai data pelatihan untuk mencari bobot yang optimal. Berdasarkan hasil pengujian sebelumnya dengan melakukan variasi parameter-parameter pelatihan, didapat konfigurasi parameter jaringan optimal dengan arsitektur 5-12-1, learning rate 0,1, nilai epoch 1500 dan target error yang digunakan sebesar 0,0001 .

Berdasarkan hasil pengujian sebelumnya dengan melakukan variasi parameter-parameter pelatihan, didapat konfigurasi parameter jaringan optimal sebagai berikut.

- Arsitektur jaringan

- Jumlah neuron input

- Jumlah neuron lapisan tersembunyi

- Jumlah neuron output

- Konstanta belajar(learning rate)

- Maksimum iterasi (epoch)

- Target error (goal)
: 5-12-1

$: 5$

$: 12$

$: 1$

$: 0,1$

$: 1500$

$: 0,0001$

Hasil pelatihan dengan menggunakan parameter-parameter di atas dan sampel data masukan masing-masing sebanyak 110 untuk tahu murni yang dapat diidentifikasi oleh jaringan sebagai tahu murni sebanyak 110 data dan yang dapat diidentifikasi oleh jaringan sebagai tahu berformalin sebanyak 0 data. Dengan kata lain semua masukan tahu murni dapat diidentifikasi oleh jaringan dengan baik. Kemudian tahu berformalin yang dapat diidentifikasi oleh jaringan sebagai tahu berformalin sebanyak 110 data dan yang dapat diidentifikasi oleh jaringan sebagai tahu murni sebanyak 0 data. Diperoleh recognition rate atau tingkat akurasi system sebesar 100\% dengan MSE sebesar 0,0099943. Dengan kata lain semua masukan tahu berformalin dapat diidentifikasi oleh jaringan dengan baik dan terlihat semua data dapat dikenali dengan tepat.

\subsection{Hasil Proses Pengujian}

Setelah melewati tahap pelatihan, dengan menggunakan konfigurasi optimal akan diperoleh bobot dan bias. Kemudian bobot dan bias ini digunakan selanjutnya untuk tahap pengujian. Pengujian ini dilakukan untuk mengetahui apakah jaringan tersebut dapat mengenali target yang telah ditentukan. Data pengujian sebanyak 80 data yang terdiri dari sampel tahu murni dan tahu berformalin. Adapun untuk tahu murni terdiri dari 40 data yang diambil dari 3 tempat (pasar colombo, pasar kranggan dan swalayan). Sedangkan tahu berformalin sebanyak 40 data dengan kandungan formalin $2 \%$. Kemudian pengujian terhadap jaringan yang telah dilatih ini terdiri dari 5 masukan dan 2 target. Hasil pengujian terhadap 80 data uji diperlihatkan pada Tabel 4

Tabel 4 Hasil pengujian dari sampel tahu

\begin{tabular}{|c|c|c|c|}
\hline \multicolumn{4}{|c|}{ Kelas Prediksi (Target Class) } \\
\hline \multirow{3}{*}{ 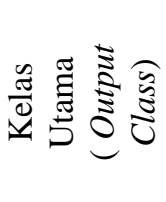 } & & Tahu Murni & Tahu Berformalin \\
\hline & Tahu Murni & $\begin{array}{l}\text { True Positives } \\
\text { (40 data) }\end{array}$ & $\begin{array}{c}\text { False Negatives } \\
\text { (0 data) }\end{array}$ \\
\hline & Tahu Berformalin & $\begin{array}{l}\text { False Positives } \\
\text { (0 data) }\end{array}$ & $\begin{array}{l}\text { True Negatives } \\
\text { (40 data) }\end{array}$ \\
\hline
\end{tabular}

Tabel 4 memperlihatkan bahwa pada true positives mengacu pada tupel positif yaitu tahu murni yang memiliki data uji sebanyak 40 dikelompokkan dengan benar sebagai true positives. Sedangkan pada true negatives merupakan tupel negatif dari data uji tahu berformalin dengan data sebanyak 40 dan dikelompokkan dengan benar sebagai true negatives. Kemudian untuk false positives dan false negatives masing-masing memiliki nilai 0 , dimana nilai 0 ini menandakan bahwa tidak ada data yang salah. Sehingga dapat dikatakan hasil uji tepat sesuai 
target yang telah diberikan. Kemudian didapatkan pula nilai akurasi, sensitivitas, dan spesivitas dari hasil pengujian. Sensitivitas dapat disebut sebagai angka positif benar (true positives) yang besarnya sebanding antara tupel positif yang dikenali benar dengan jumlah keseluruhan dari data pada tupel positif. Sedangkan spesivisitas adalah angka negatif benar yang besarnya sebanding antara tupel negatif yang dikenali benar dengan jumlah keseluruhan dari data pada tupel negatif.

Dari hasil analisa penelitian ini dapat menunjukkan bahwa jaringan dapat mengenali data yang telah diberikan dengan akurasi $100 \%$. Sehingga dapat dikatakan bahwa jaringan syaraf backpropagation memiliki keseimbangan antara kemampuan jaringan untuk mengenali pola selama proses pelatihan dan jaringan mampu memberikan respon yang benar terhadap pola masukan yang serupa (tetapi tidak sama) dengan pola yang digunakan selama pelatihan.

\section{KESIMPULAN}

Berdasarkan penelitian yang telah dilakukan maka dapat diambil kesimpulan sebagai berikut

1. Telah berhasil dilakukan identifikasi tahu murni dan tahu berformalin dengan electronic nose menggunakan analisa jaringan syaraf tiruan backpropagation.

2. Untuk mengidentifikasi bau formalin pada tahu yang sensitif terhadap gugus $\mathrm{OH}, \mathrm{CO}$ dan gugus hidrokarbon digunakan sensor keluaran Figaro, TGS 2610, TGS 2600, TGS 2620, TGS 2602 dan TGS 2611.

3. Parameter jaringan yang digunakan yaitu 5 layer pada neuron input, 12 buah neuron pada layer tersembunyi (hidden layer) dan 1 buah neuron pada layer output, nilai learning rate 0,1 .

4. Seluruh sampel tahu uji acak (80 data) dapat diidentifikasi dengan baik (100\%) oleh JST-BP dengan nilai MSE 9,6374 $\times 10^{-3}$.

\section{SARAN}

Saran yang disampaikan penulis untuk pengembangan penelitian yang akan datang adalah sebagai berikut

1. Sistem dapat dikembangkan dengan menghubungkan antara electronic nose dengan perangkat lunak secara langsung, sehingga pengambilan data dan identifikasi dapat dilakukan dalam waktu yang sama, sehingga proses identifikasi tidak perlu menggunakan GC (Gas Chromatography).

2. Perlunya penelitian di bidang jaringan syaraf tiruan dengan menggunakan metode lainnya untuk proses identifikasi, kemudian dilakukan perbandingan sehingga dapat mengetahui metode mana yang efektif untuk melakukan analisa data pada $e$-nose.

\section{DAFTAR PUSTAKA}

[1] Rulcker, C.,K., Stenberg M., Winquits, F., Lundstrom, I., 2001, Electronic tongues for environmental monitoring based on sensor arrys and pattern recognition: a review. Analytica Chimica Acta 426 (2001) 217-226.

[2] Lelono, D., 2014, Rancang Bangun Hidung Elektronik (Electronic Nose) Untuk Klasifikasi Kualitas Teh Hitam, Proposal Dana Hibah FMIPA tahun 2014.

[3] Scott, S., M., James, D., Ali, Z., 2006, Data analysis for electronic nose systems. Microchim Acta 156: 183 
[4] Zupan, J., 1994, Introduction of artificial neural network (ANN) methods: what they are and how to use them. Acta Chimica Slovenica 41: 327.

[5] Scampicchio, M., Ballabio, D., Arecchi, A., Cosio, S.,M., Mannino, S., 2008, Amperometric electronic tongue for food analysis. Review. Microchim Acta. 163: 11-21

[6] Iswanto, W, 2014, Rancang Bangun Electronic Nose untuk Mengklasifikasikan Pola Bau Tahu dan Tahu Berformalin, Skripsi, Elektronika dan Instrumentasi, Universitas Gadjah Mada, Yogyakarta. 